\title{
After early retirement: the variety of human-resource strategies of firms towards older employees
}

\author{
Martin Brussig ${ }^{1 *}$ and Ute Leber $^{2}$
}

\begin{abstract}
Over the last years, the employment rate of older workers has increased sharply in Germany. Against this background, the question arose as to whether firms have contributed actively to the growing share of older employees, either by offering special human resource management (HRM) measures, such as further training (internal strategy) or by hiring older employees from the external labour market (external strategy). Our paper analyses the interrelation between both strategies. By using data from the IAB Establishment Panel, we investigate the determinants of the firms' decision to use one or the other strategy or to combine both strategies. Our analyses show that some factors, such as firm size, experiences with older staff or a shortage of skilled workers promote the decision for both strategies. Other characteristics, in contrast, have a positive effect on one strategy only. This applies in particular to industrial relations, but also to the share of qualified workers within a company.
\end{abstract}

Keywords: HRM, Demographic change, IAB Establishment Panel

\section{Introduction}

The age structure of employed persons in Germany has changed significantly over the past years. The rate of older employees (i.e. the share of older employees in the population between 55 and 65 years) has almost doubled in the course of only 10 years. Meanwhile, every fourth employee is at least 50 years old. This illustrates a demographic change in which the baby boomers increasingly reach ages close to retirement and the upcoming cohorts shrink or remain at a constantly low level. Reforms in the pension politics and in labour market politics have set strong incentives to extend the employment phase and reduce opportunities for early retirement. However, these reforms, for instance the increase of the regular retirement age from 65 to 67 years and the abolition of promoted partial retirement, are met with wide opposition because critics claim that the conditions for an extended

\footnotetext{
*Correspondence: martin.brussig@uni-due.de

${ }^{1}$ Institut Arbeit und Qualifikation (IAQ), Universität Duisburg-Essen,

47048 Duisburg, Germany

Full list of author information is available at the end of the article
}

working life frequently do not exist. In fact, all available studies show significant differences in the employment opportunities of older people, be it by sex, qualification or profession. ${ }^{1}$ Since employment takes place within companies, we assume that primarily the working conditions in companies in a wide sense, i.e. including e.g. HRM-policies and industrial relations, are what encourage for or interfere with long-term employment until retirement age.

However, we know only little about in-company human resource management regarding older people after the era of early retirement. ${ }^{2}$ Early retirement, a standard option for enterprises in past years, is now closed or at least more expensive for enterprises. In particular, we do not know to which degree companies have actively contributed by using personnel management strategies to employ more older people today than 10 years ago or

\section{Springer Open}

(c) The Author(s) 2019. This article is licensed under a Creative Commons Attribution 4.0 International License, which permits use, sharing, adaptation, distribution and reproduction in any medium or format, as long as you give appropriate credit to the original author(s) and the source, provide a link to the Creative Commons licence, and indicate if changes were made. The images or other third party material in this article are included in the article's Creative Commons licence, unless indicated otherwise in a credit line to the material. If material is not included in the article's Creative Commons licence and your intended use is not permitted by statutory regulation or exceeds the permitted use, you will need to obtain permission directly from the copyright holder. To view a copy of this licence, visit http://creativeco mmons.org/licenses/by/4.0/.

\footnotetext{
${ }^{1}$ Cf. the research reports about "Gute Erwerbsbiographien" or the ongoing reports of the "Altersübergangs-Monitor". Cf. Trischler and Kistler (2010), and Kistler and Trischler (2014), as well as Brussig and Knuth (2011).

2 The conditions of early retirement have been evaluated in depth, cf. in summary Rosenow (2000) and Fröhler et al. (2013).
} 
whether the ageing of staff simply results from demographic change and longer stays in the company, which companies accept passively but do not support actively. The persistently low dissemination of special personnel management for older workers (Leber et al. 2013) and the almost constantly low entry rates of older people into new employment (Brussig 2011) seem to indicate that companies more or less accept passively the ageing of their staff. Yet, companies have the possibility of meeting the opportunities and risks of demographic ageing for their human capital. They can do so by designing tasks, work places, team structures etc. and thus influencing working conditions in a wide sense aiming at retaining older workers on the one hand, and by recruiting strategies on the other, or by a combination of both. We call these options in this paper as the internal and external strategy in dealing with older employees.

Our paper analyses the interdependencies between the internal and external strategies of personnel management at a company level. The research question of our paper is how both strategies are related to each other at company level: Are they complementary (or substitutive) or cumulative to each other? Do they tend to exclude each other, or can external and internal strategies be combined? In the next section, we argue that both strategies can be justified in theory. An empirical evaluation of this question does not only contribute to describing personnel management in times of demographic change but also-through the confirmation or dismissal of the theoretical arguments-to a better understanding of the circumstances under which a further extension of working lifes is possible.

The present paper is structured as follows: Sect. 2 presents theoretical considerations regarding the employment of older employees and derives the detailed questions and hypotheses of this paper. Section 3 describes the data basis used and explains the strategy of the data analysis. Section 4 presents the empirical results and Sect. 5 discusses the consequences for employment opportunities of older people and draws some conclusions for further research.

\section{Theoretical considerations, state of the art and hypotheses}

Employment contracts are characterised by being open and vague (or not completely determined) regarding the exact conditions of the exchange of performances (Akerlof 1982; Crozier and Friedberg 1979). This vagueness can be reduced by explicit and implicit agreements regarding the intended period of employment and thus, job commitment. As different theories of internal labour markets have shown, the extent of job commitment hence becomes a significant resource and restriction for personnel management (Doeringer and Piore 1971; Lutz and Burkart 1987; Osterman and Paul 1994; Köhler 2008). The implicit job guarantee given by the company leads to age effects in staff: The individual capacity to perform might change with age and the extent of age-related fluctuation in a company depends on the age distribution among the staff.

Thus, the age structure of the staff is both a result of and a condition for the human resource management of the firm. Empirical studies show that companies manage implicit contracts strategically resulting in downright "age policies" or "life career policies" (Struck 2000). However, traditional life career policies are turned upside down under the conditions of the demographic change and early retirement regulations drawing to a close. Older employees are then considered less of an "adjustment resource" (Rosenow 2000), who are pushed out of the company via early retirement although they are still able to perform, but they tend to remain part of the staff even if their capacity or willingness to perform decreases.

Under these changed circumstances, companies can both invest in staff-in particular in older employeesto allow extended working periods, and increasingly consider older applicants. From a theoretical point of view, however, the decision calculus of companies is not conclusive.

Under investment-theoretical aspects, as put forward in particular by human capital theory (Becker 1993, Mincer 1994), investments in existing staff, on the one hand, and acceptance of older applicants, on the other hand, exclude each other. Both options require investments, which are scarce. An internal HRM-strategy requires investments in existing staff, while an external HRM-strategy requires costs for recruitments. Since new recruitments work side by side with workers who are in the firm since long-they work together in the same work teams-it is not possible for the firm to confine their investments on workers with a long tenure. Older workers who have been recently recruited will spend less time in the firm until they retire. Compared to younger workers and to (older) workers with a long tenure, this increases for an internal strategy the costs of hiring older workers. From the perspective of human capital theory, a complementary (or substitutive) relation between internal and external strategies can be expected.

A complementary relationship of the two basic personnel management procedures must be expected also from the point of view of segmentation theories. The loyalty promise of internal markets becomes expensive in particular with older employees and leads to a shutdown towards external applicants (Osterman and Paul 
1994, Althaauser and Kalleberg 1981, Marsden 1999). From the point of view of segmentation theories, however, recruiting external applicants might be rational under the condition of "open employment systems" but would impede the development of sophisticated internal measures aimed at retaining older workers (cf. Köhler et al. 2008, Sengenberger 1987). Again, external and internal strategies seem to exclude each other.

However, there are also good reasons for a combination of both approaches. The (continued) employment of older people can lead to trust in their capacity to perform and result in experiences in dealing with them, which allow a better assessment of the risks arising from hiring older people. Human resource problems in individual companies can become so high in extreme cases that all available measures are taken or that-as part of the recruitment strategy-the attractiveness of the company is highlighted by age-appropriate work design.

Empirical studies on internal personnel management towards older employees confirm investment-theoretical considerations of human capital or segmentation theory only in a limited way. First, one has to concede that only a few enterprises regard older employees as a valuable resource (van Dalen et al. 2009 in European comparison; Bellmann and Leber 2008 and Leber et al. 2013 for Germany). Brussig (2007) evaluated the determinants of measures specifically tailored to older employees based on the IAB Establishment Panel. The two strongest influencing factors were company size and existence of a works council. Both factors point to the fact that HR management targeted at older employees plays a (minor) role in the HR management of the overall company. Rather, policies towards older employees are negotiated between the works council and management. Göbel and Zwick (2010) indirectly confirm the company-politicy argument by showing that only selected measures of HRM for older people increase productivity, such as work design and work teams with a heterogeneous age distribution but not flexible working hours or special further training offers for older people. The fact that nonage-related measures have an effect specifically on older workers suggests a mediating effect that could exist in the negotiation processes between the management and works council.

These findings from quantitative research, mainly based on the IAB Establishment Panel, are also confirmed by practical research and case studies which show that a systematic age management of companies is rather an exception than the rule (e.g., Brandl et al. 2018, Richter and Mühlenbrock 2018 or Rump and Eilers 2007). As these studies illustrate, many companies still pursue a youth-oriented personnel policy and have maintained their activities towards older employees at a continuing low level-despite a high awareness of the demographic challenges. This reflects a "knowing-doing gap": Even though there is a lot of information and knowledge available to employers, their actual doing is lagging behind (Ilmarinen 2017).

The results of studies on recruitment of older employees are more obvious at first sight: an effect impeding recruitment could be observed in companies remunerating by seniority (Hutchens 1986; Daniel and Heywood 2007; Zwick 2009a, b; Machado 2012). The situation is less obvious with regard to further characteristics. For instance, Heywood et al. (2010) showed a negative correlation between the share of older employees in a company and the probability to recruit older people, while Brussig and Bellmann (2008) identified a positive-albeit weak-correlation. The reason for these divergences could, however, be shortcomings in the empirical design of both papers, because both papers view the share of older employees as an endogenous variable without considering that this share is influenced by the recruitment of older people. Also, the papers do not take specific HR management measures for older people into account.

Taken empirical studies about age-related internal HRM-strategies and studies about recruitment of older applicants together, they give some support for the idea that advanced age-related HRM-measures and recruitment of older workers exclude each other. However, the results are not robust, and the underlying studies have some methodological shortcomings.

To understand the company-specific conditions of employing older people, one must also understand the interrelations between human resource measures for older people and the recruitment behaviour towards older people. This has not been empirically examined to date. The questions in this regard are, therefore:

(1) Which characteristics at enterprise level encourage or impede offering HR-measures for older people?

(2) Which characteristics at enterprise level encourage or impede recruiting older people?

(3) Which characteristics have firms using both HRmeasures for older people and recruitment of older people and which circumstances lead to them excluding each other?

The present analysis focusses on these aspects in accordance with the considerations above. We will have a focus on resources, work relations, experiences with older workers, problems in finding new employees and work requirements. We expect the following factors to be (positively or negatively) linked to the offer of HRM 
measures for older people and/or the recruitment of older people.

- Initially, we assume that a company's resources are more decisive regarding the offer of HR-measures than regarding recruitment because HR- measures rely more strongly on investment costs than recruiting behaviour. The decision to accept applications by older employees alone does not incur additional costs while the decision in favour of, for example, ageappropriate workplace design directly entails additional costs. Thus, it is possible that age-related personnel measures are prevalent in companies, which already feature a number of personnel management instruments for all employees within the firm. Hence, characteristics such as company size, institutionalisation of personnel management and development should be relevant. Since a company's resources also influence the possibilities for initial training of new recruits, we also assume a positive correlation with recruitment.

- Work relations (or industrial relations) should also correlate positively with the offer of age-specific HRmeasures. We expect that companies with a works council or bound by collective agreements are characterised by a stronger (formalised) influence of staff, which should also lead to stronger co-determination in personnel issues and thus, also to age-appropriate personnel policies in alignment with employee interests. We assume a special protection of insiders in particular if a works council exists. Hence, already employed older employees should be promoted and maintained in the company using age-specific HRMinstruments, while older outsiders should not be in the focus of works council actions. Consequently, we can assume a rather negative influence on recruitment if a works council or a binding collective agreement exists.

- The experiences companies have with older employees should positively affect the use of age-specific HR-management tools and recruitment of older people. We assume that companies that have had positive experiences with older employees are particularly interested in committing these employees to the company and are consequently more ready to invest in their employability. Also, recruiting older people seems more probable in this case.

- We assume that companies experiencing difficulties in meeting their demand for skilled workers are particularly interested in utilising the (partly not yet fully) tapped potential of older employees. On the one hand, this can be achieved by investing into the employability of already existing older employ- ees, and on the other hand, by recruiting external older people. Therefore, we consider the companies' demand for skilled workers in our empirical analysis. We also take account of the labour turnover within a company. As a high turnover rate implies a high need of workers, we assume that the turnover rate exerts a positive effect on the recruiting of (older) employees. The effect on the use of age-specific HR-measures, in contrast, should be negative as firms should only be willing to invest in the employability of their workers if they stay with them for at least a certain time.

- Finally, we expect that the behaviour of companies towards older employees is also determined by the specific job requirements and the work environment. We describe the job requirements and the work environment by means of the share of employees for qualified jobs, technical equipment and industry affiliation. Since qualified jobs are usually more demanding and complex, we assume that the share of employees for qualified jobs is positively linked to the implementation of HR-measures towards older employees. This should particularly apply to HR-measures such as further training for older employees. The connection with recruiting older people, in contrast, is not clear. The effects of technical equipment and industry affiliation are hard to evaluate a priori: Technical innovations can lead to a certain degree of adjustment requirement, which may be covered by the offer of respective personnel measures. If technical equipment or the investments made are very specific (and require firm-specific training), this might speak against external recruiting but in favour of promoting already employed employees. Regarding industryaffiliation, we assume that companies in industries dominated by physically straining activities rather refrain from recruiting older people but try to maintain the employability of their older employees until the end of their professional life by offering appropriate measures. However, we need to consider that the industry is not only a proxy variable for typical work stress, but that there are, for example, also industryspecific fluctuation and recruitment patterns as well as seasonal variations, which can interfere with the effect of work stress.

\section{Dataset and strategy}

To answer the questions raised above, we use the data of the IAB Establishment Panel. The IAB Establishment Panel is a representative survey among companies of all industries and sizes, which has been conducted annually in Western Germany since 1993 and in Eastern Germany since 1996 (for further information regarding 
the IAB establishment panel cf. Bellmann 2014). The IAB Establishment Panel is a survey covering several issues. While some issues, such as personnel structure and development or investments, are surveyed annually, others are surveyed in individual years only. The question regarding personnel policies geared towards older people, which we focus on is such a special subject that was surveyed in 2002, 2006, 2008 and 2011. The companies employing older employees (defined in the IAB Establishment Panel as employees aged 50 or over) received a list of different HRM measures for older employees. Although the IAB Establishment Panel is a valuable source to analyse questions concerning HRM policies towards older employees, it comes at the same time with significant restrictions. First, one has to consider the specific characteristics of quantitative compared to qualitative data. For instance, information about the enterprises can be obtained only in a standardized way. Second, the IAB Establishment Panel provides information only on the incidence but not on the intensity of given elements of HRM-strategies within a company. If a company provides further training for older employees, we do not know whether this offer affects all or just a few older employees. Within these restrictions, the answers can be regarded generally as valid (cf. Bellmann 2014).

The HRM instruments which have been asked for in the IAB Establishment Panel include activities of health promotion, special further training for older workers, the special equipment at the workplace, the adjustment of performance requirements, the inclusion of older workers in general (not age-specific) further training, mixedage teams, and partial retirement (see Fig. 1 in Sect. 4.1). This catalogue of instruments covers a broad range of instruments, even though some instruments discussed in the literature are missing (e.g., the role of leadership or age-specific training measures for managers, cf. Stecker and Zierler 2018). Each of the instruments covered by the IAB Establishment Panel has specific requirements and targets into different directions.

- Inclusion of older workers in general (not age-specific) further training: Further training attempts to keep workers up to date with new technologies and organizational changes. It therefore increases their employability.

- Special further training for older workers: This assumes that learning and training works different for older workers than for younger workers. It might be useful, then, to differentiate further training programs according to age.

- Special equipment for work places: Special equipment for work places is common for handicapped and disabled workers. Special equipment might be also implemented to prevent work strains. Older workers benefit from special equipment in particular, but the implementation of special work place equipment is not restricted to older workers.

- Adjustment of performance requirements: An adjustment of work requirements might include a

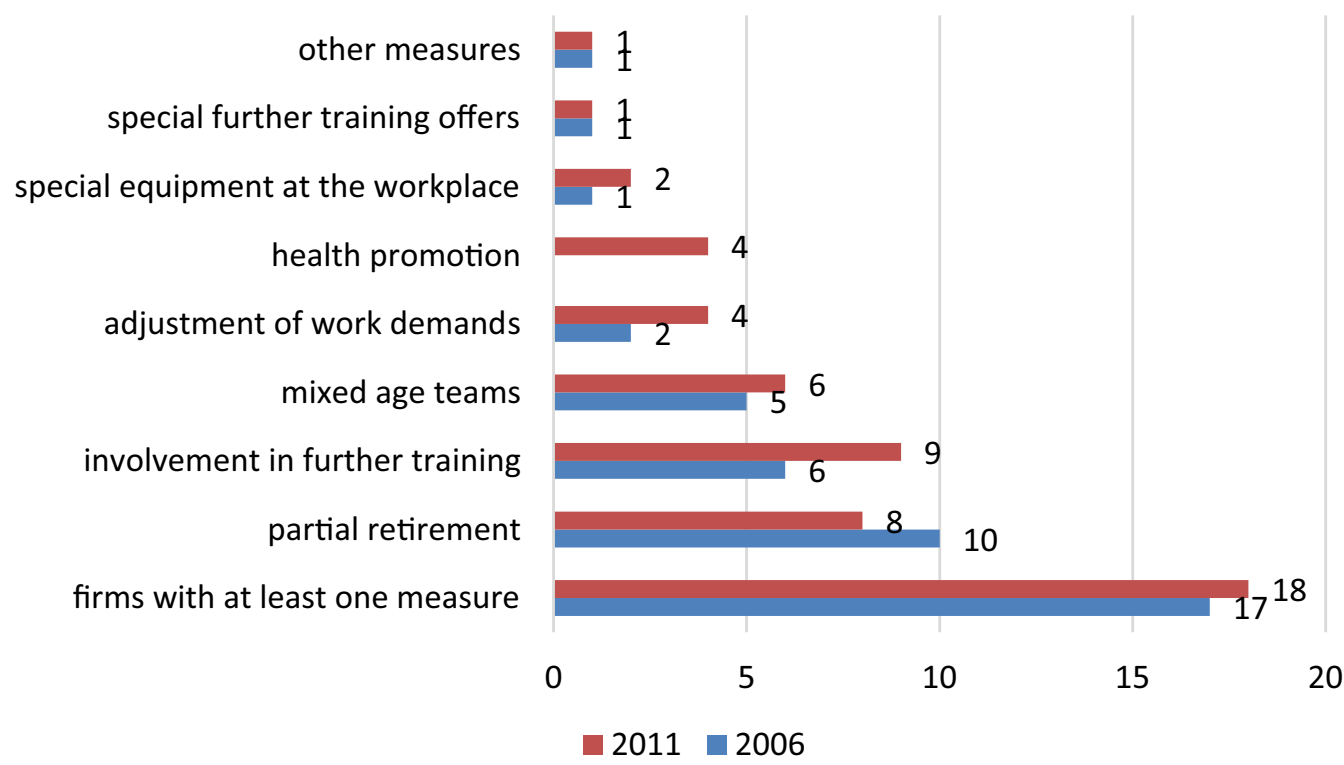

Fig. 1 Personnel measures towards older employees 2006 and 2011 (in percent). Basis: All establishments with older employees. Source: IAB Establishment Panel, own calculations 
lowering of work demands as well as a reorganisation (e.g. more holistic and less fragmented work requirements), which reduces work strains.

- Mixed-age teams: Mixed-aged teams might be used as an instrument to make use of age-related virtues, such as experience and loyalty from older and willingness for innovation from younger workers. Mixed-age teams as an HR instrument do not aim primarily at an increase of individual employability, but on group productivity.

- Activities for health promotion: Health promotion include a wide array of instruments-mostly offered on a voluntary basis-aiming at prevention. Even if they take place within the enterprise, activities for health promotion are usually separated from the work process (in contrast to, e.g. mixed-age teams or special equipment).

- Partial retirement: Partial retirement is a doublededged sword. In most cases, it us used as an instrument for early retirement, but it might be used as an instrument to prolong working lifes. Enterprises often use partial retirement programs to help older workers to cope with increasing age-limits in the pension insurance. In this respect, partial retirement programs are an important bridge instrument in post-early-retirement HRM.

Since some of our explaining variables (e.g., the instruments of personnel management that are included in the HRM-index, see Table 1) are missing in earlier waves of the IAB-Establishment Panel, we focus our analysis on the latest data (i.e. that of 2011). This means that we cannot say anything about potential changes in the drivers of the internal and external strategy over time, but our analyses can contribute to a deeper understanding of the age management practices of companies at a specific point in time.

The IAB Establishment Panel contains information regarding recruitment of employees, but these data are not differentiated by age. Since we are interested in the recruitment of older people in particular, we additionally used data from the Federal Employment Agency's (Bundesagentur für Arbeit, BA) employment statistics, which allow differentiating new recruits by their age. Based on the IAB Establishment Panel, we also defined older employees as persons aged 50 years or above. We use the employment statistics to obtain information for every company in the IAB Establishment Panel regarding how many persons $50+$ were recruited in the first 6 months of 2011.

For our empirical analysis, we differentiated companies by whether they offer at least one HRM measure towards older people on the one hand and whether they recruited (at least) one older person on the other hand. Although the measures are not (complete) substitutes, the existence of at least one age-specific HRM instrument indicates a minimal awareness for age-related HRM. This resulted in four types: Companies offering both age-specific HRMmeasures and having recruited older people; companies offering only age-specific HRM-measures; companies only having recruited older people; and companies having done neither (see Table 2). This operationalisation does not focus on how many older people are recruited or which and how many or which age-specific personnel measures are implemented but more on the choice of both strategies. Hence, we will present the results of logit

Table 1 Operationalisation of the explanatory variables. Source: Own figure

\begin{tabular}{|c|c|c|c|}
\hline & Operationalisation & $\begin{array}{l}\text { Expected correlation } \\
\text { with the provision of age- } \\
\text { specific personnel measures }\end{array}$ & $\begin{array}{l}\text { Expected correlation } \\
\text { with the recruitment } \\
\text { of older employees }\end{array}$ \\
\hline \multirow[t]{3}{*}{ Resources } & Company size (log number of employees) & + & + \\
\hline & $\begin{array}{l}\text { HRM-Index (index which specifies how many instruments of } \\
\text { personnel management (e.g., qualification-need analyses, target } \\
\text { agreements) a company uses; can take values between } 0 \text { and } 3\end{array}$ & + & + \\
\hline & Provision of further training (Dummy) & + & + \\
\hline \multirow[t]{2}{*}{ Context of work relations } & Existence of a works council (Dummy) & + & - \\
\hline & Commitment to a collective agreement (Dummy) & + & 0 \\
\hline $\begin{array}{l}\text { Experiences with older } \\
\text { employees }\end{array}$ & Share of older employees (in the previous year) & + & + \\
\hline Needs for skilled workers & $\begin{array}{l}\text { Company experiences difficulties in meeting its demand for skilled } \\
\text { workers (Dummy) }\end{array}$ & + & + \\
\hline \multirow{4}{*}{$\begin{array}{l}\text { Job requirements and } \\
\text { work environment }\end{array}$} & Modern technical equipment (Dummy) & + & 0 \\
\hline & Investments in company equipment and/or ICT & + & 0 \\
\hline & Share of skilled employees & + & 0 \\
\hline & $\begin{array}{l}\text { Sector affiliation (10 dummies; Reference category: public adminis- } \\
\text { tration/non-profit organisations) }\end{array}$ & 0 & 0 \\
\hline
\end{tabular}


Table 2 Types of personnel strategies at enterprise level (dependent variable). Source: Own figure

\begin{tabular}{llll}
\hline & & \multicolumn{2}{l}{$\begin{array}{l}\text { Offer of at least one age- } \\
\text { specific HR measure }\end{array}$} \\
\cline { 2 - 4 } \cline { 3 - 4 } $\begin{array}{c}\text { Recruitment of older employees } \\
\text { (during the last } 6 \text { months) }\end{array}$ & Yes & Type 4 & Type 2 \\
\hline
\end{tabular}

estimations in which the offer of at least one age-specific HRM-instrument and recruitment of older employees (yes-no) represent the dependent variables. To gain a better understanding of the correlation of both strategies, we supplement these analyses with multinomial logit estimations aiming to explain the affiliation of companies with one of the four groups (see above and Table 2).

\section{Results}

\subsection{Large differences by size and industry} both with personnel measures and recruitment

Only a minority of firms has implemented HR instruments for older workers, and nearly all of them use only a small selection of instruments A total of $18 \%$ of companies which employed older workers offered one of the measures recorded by the IAB Establishment Panel in 2011. As compared to the previous years, this does not show a significant change of the share of companies with age-related HR-instruments. In 2006, for instance, $17 \%$ of companies have implemented these instruments. However, the offer of age-specific HR-instruments varies significantly between companies of different size categories: While in 2011 almost all large-sized companies with 500 and more employees have implemented at least one age-related HR instrument, only one out of ten small enterprises (less than 20 employees) did so. There are also differences between companies of different industries: Age-specific HR instruments are implemented far above average in public administration/social insurance as well as in mining/energy/water. In contrast, the implementation of these instruments is below average in agriculture and forestry, the construction industry and commerce. When considering the HR instruments in more detail, it can be seen that-besides partial retirement, which is more geared towards the preliminary exclusion of employees-in particular the inclusion of older people in further training plays the most important role in practice. The other activities are only offered by a very small fraction of enterprises (1 to 6\%) of companies (see Fig. 1).

2011, recruitment of older workers only took place in roughly four out of ten companies that were recruiting at all. A size effect can be observed here, too: The probability that at least one employee over 50 years of age is recruited is higher in large companies than in small ones. This is because large companies recruit more people than small companies, which might lead to an older person being among the new recruits more frequently. When differentiating by industries, it can be observed that the share of companies having recruited at least one older employee was particularly high in the processing industry in 2011. It was below average in the construction industry as well as in agriculture and forestry. However, with such industry comparisons, it should be taken into account that different effects interfere with each other. Industry-specific size structures of the companies play an important role. As compared to 2006, there is quite a significant increase of companies having recruited older people.

What is the relation between recruitment and agespecific HR measures? Do companies tend to rely on one strategy only or do they combine both options? Our analysis shows that almost half of the companies (46\%) offered neither HR measures for older people nor recruited older employees in 2011 . Hence, they pursued neither the internal nor the external approach (Table 3). Almost one-third of companies recruited people over 50 years of age but did not invest in the employability of older people by offering respective measures. $12 \%$ of companies used both internal and external strategies, and $10 \%$ offered age-specific HR measures but did not recruit older people. Therefore, we can conclude that companies combining both strategies are quite rare, while a significant share recruits older employees without offering special personnel measures for their older staff.

Mostly larger companies offer both recruiting of older people and age-specific personnel measures. Due to organisational complexity (number of positions, jobs, departments and HR decision-makers), there is a better chance of some form of age-specific personnel policy in larger companies. That does not mean necessarily, however, that all (older) employees would benefit. Smaller companies, on the other hand, more frequently use none of the strategies or decide in favour of only one of them. It can be seen in Table 3 that (exclusive) recruitment of older people is more prevalent in smaller companies than age-specific HR instruments are. The situation is less obvious when considering the distribution of the company types by industry affiliation. For instance, commerce as well as infrastructure and news transmission, recruit older people frequently above average but practice HR-instruments for older people below average only. This is the other way round, for instance, in companyrelated as well as other services where companies implemented age-specific programmes above average but are below average in terms of recruiting older people. 
Table 3 Distribution of the four company types, 2006 and 2011. Source: IAB Establishment Panel; own calculations

\begin{tabular}{|c|c|c|c|c|}
\hline & $\begin{array}{l}\text { Neither recruitments } \\
\text { nor personnel measures }\end{array}$ & $\begin{array}{l}\text { Recruitments } \\
\text { but no personnel } \\
\text { measures }\end{array}$ & $\begin{array}{l}\text { Personnel measures } \\
\text { but no recruitments }\end{array}$ & Both \\
\hline & Type 1 (\%) & Type 2 (\%) & Type 3 (\%) & Type 4 (\%) \\
\hline 1-9 employees & 61 & 29 & 7 & 3 \\
\hline 10-49 employees & 40 & 35 & 13 & 13 \\
\hline 50-499 employees & 7 & 28 & 15 & 51 \\
\hline 500 and more employees & 0 & 8 & 3 & 89 \\
\hline Agriculture and forestry & 57 & 32 & 6 & 5 \\
\hline Mining, electricity, gas and water supply & 51 & 28 & 12 & 8 \\
\hline Manufacturing & 40 & 36 & 9 & 15 \\
\hline Construction & 55 & 29 & 10 & 6 \\
\hline Wholesale and retail sector & 44 & 38 & 8 & 9 \\
\hline Transport, communications & 55 & 35 & 5 & 5 \\
\hline Financial and insurance activities & 34 & 33 & 20 & 13 \\
\hline Business-related services & 54 & 25 & 12 & 9 \\
\hline Other services & 46 & 24 & 11 & 18 \\
\hline Public administration/non-profit organisations & 51 & 27 & 9 & 13 \\
\hline Total 2011 & 46 & 31 & 10 & 12 \\
\hline Total 2006 & 52 & 25 & 14 & 9 \\
\hline
\end{tabular}

As compared to 2006, the share of companies which neither recruit older employees nor installed age-specific personnel measures decreased (from 52 to $46 \%$ ). This might be caused by demographic ageing within enterprises and in the (employable) population as well. Furthermore, an increase of the share of firms with recruitment of older workers can be observed in both variants (recruitment of older applicants without agespecific internal measures: 25 to $31 \%$, and combination of recruitment of older workers and age-specific measures: 9 to $12 \%$ ), while the share of firms with a purely internal strategy has decreased (14 to $10 \%$ ).

\subsection{Determinants of the internal and external strategies}

As shown in the previous section, about half of the companies neither recruited older employees nor conducted measures for already employed people of this age in 2011. However, what differentiates these companies from those which were active in the fields mentioned? What are the differences between the companies which rely on external measures geared towards older employees and those promoting their already employed older people by pursuing internal strategies?

In the following, we will present the results of logit estimations in which we will separately examine the determinants of the implementation of age-specific HR measures and recruitment of older people as presented above. The logit estimations help to understand correlations between characteristics of an enterprise on the one hand and the existence of internal vs. external HRM-strategies on the other hand. However, it might be that both strategies interact with each other in a complementary or substitutive way. It would then be misleading to focus on isolated elements of the HRM-strategy of an enterprise, such as internal or external elements. For a better understanding of the interaction of the two strategies, we extend the logit estimations by multinomial logit estimations, which we used to analyse which factors (characteristics of the enterprises) affect the combinations of both strategies at enterprise level.

The separate estimations show that a company's resources make a substantial contribution to explaining both internal and external strategies (see Table 4). This results in a significantly positive correlation for company size both regarding recruitment and the offer of $H R$ instruments. This is not surprising, since the probability of the occurrence of one of the two strategies grows with an increasing number of employees. However, we must also consider that larger companies have more financial and organisational options to invest in the employability of employees or to recruit and train older employees. Furthermore, companies with a highly differentiated and institutionalised HR management are highly likely to offer HR instruments for older people. The same holds true for companies that are active in further training of their employees. Both variables, however, have a negative effect on the recruitment of older people. This might indicate that some companies consider (training) 
Table 4 Determinants of the implementation of age-specific HR instruments and recruitment of older people, 2011 (Logit estimations). Source: IAB Establishment Panel 2011; own calculations

\begin{tabular}{|c|c|c|}
\hline & $\begin{array}{l}\text { Implementation of age-specific HR instruments } \\
\text { Internal strategy }\end{array}$ & $\begin{array}{l}\text { Recruitment of older workers } \\
\text { External strategy }\end{array}$ \\
\hline \multicolumn{3}{|l|}{ Resources } \\
\hline Company size & $0.590^{* * *}(0.026)$ & $0.889^{* * *}(0.027)$ \\
\hline HRM-index & $0.293^{* * *}(0.027)$ & $-0.051^{*}(0.026)$ \\
\hline Further training & $0.749^{* * *}(0.082)$ & $-0.339^{* * *}(0.065)$ \\
\hline \multicolumn{3}{|l|}{ Experiences with older employees } \\
\hline Share of older employees & $1.828^{* * *}(0.159)$ & $1.822^{* * *}(0.139)$ \\
\hline \multicolumn{3}{|l|}{ Context of work relations: } \\
\hline Works council & $0.743^{* * *}(0.064)$ & $-0.162^{* * *}(0.065)$ \\
\hline Collective agreement & $0.362^{* * *}(0.060)$ & $-0.167^{* *}(0.058)$ \\
\hline Need for skilled workers & $0.269^{* * *}(0.059)$ & $0.187^{* * *}(0.056)$ \\
\hline Labour turnover & $-0.105^{* * *}(0.033)$ & $1.328^{* * *}(0.148)$ \\
\hline \multicolumn{3}{|l|}{ Job requirements/work environment } \\
\hline Share of skilled workers & $0.493^{* * *}(0.117)$ & $-0.380^{* * *}(0.104)$ \\
\hline Modern technical equipment & $0.021(0.061)$ & $-0.021(0.054)$ \\
\hline Investments & $0.232^{* * *}(0.060)$ & $-0.083^{* *}(0.054)$ \\
\hline Sector affiliation (10 dummies) & Incl. & Incl. \\
\hline N & 9240 & 9240 \\
\hline Pseudo $R^{2}$ & 0.3465 & 0.1876 \\
\hline
\end{tabular}

Basis: Establishments with older employees and recruitments

${ }^{*} p<0.10,{ }^{* *} p<0.05,{ }^{* * *} p<0.01$; standard errors in parentheses

investments in already employed persons as an alternative strategy to recruitment and refrain from recruiting if existing qualification requirements can be met by internal activities.

We used the share of older employees as an indicator to describe companies' experiences with older employees. This indicator has a highly significant positive effect both on the use of the internal strategy as well as external strategy. Consequently, companies seem more likely to invest in the employability of their older employees as well as recruiting older employees if they have substantial experiences with this group of employees. This confirms our hypothesis about the importance of experience with older workers for HRM-policies towards older workers. Our assumption regarding the context of work relations can also be verified empirically. Companies bound by collective agreements and companies with a works council have a higher probability of implementing HR- measures for older employees but a lower probability of recruiting older employees. This might indicate a certain degree of protection of already employed persons due to the abovementioned co-determination boards or institutions.

Companies that are confronted with a high requirement for skilled workers are more likely to offer HRmeasures for their older employees but are also more likely to recruit older employees. This, too, confirms our hypothesis and can be interpreted in such a way that companies try to meet their demand for skilled workers in different ways and do not only tap their own potentials. Instead, they try to make use of external resources as well. A high labour turnover exerts a negative effect on the use of internal strategies whereas it is positively connected with the use of the external strategy. Companies with a high fluctuation of their employees seem to have a high demand for labour and are therefore more likely to recruit (older) employees from the external labour market. On the other hand, a high turnover reduces a company's incentive to invest in the employability of its existing staff as it might be questionable whether these investments pay off.

The specific job requirements, operationalised here through investments and the share of employees for qualified jobs, are positively connected with the utilisation of internal strategies but negatively connected with the utilisation of external strategies. Apparently, with specific job requirements, the existing staff is more taken care of than taking the risks of "unfitting" recruits. A company's technical equipment does not lead to a significant effect.

A comparison of the pseudo $R^{2}$ finally shows that the model can explain the choice for the internal strategy about twice as good as the choice for the external 
strategy. One might suppose that recruitment (and in particular, recruitment of older employees) depends less on factors of the company structure and more on HR requirements.

The findings of these estimations performed separately for the internal and external strategies are largely confirmed when examining how the different factors are connected with the four company types resulting from the combination of internal and external strategies (see Table 5). The multinomial analysis was undertaken to test whether the internal and external strategy contradict each other at enterprise level. The results of our multinomial logit estimations show that in particular, company size and the share of older people in a company promote a choice for only one strategy (external or internal, types 2 and 3) but in particular, the choice for a combination of internal and external strategies (ype 4). The same holds true for the existence of a requirement for skilled workers as an HR problem.

Highly differentiated or institutionalised personnel policies, on the other hand, have a positive effect on the implementation of HR instruments for older people in particular (Type 3) but also on the joint implementation of internal and external strategies (Type 4). A high labour turnover increases the probability of being a Type 2 or 4-company whereas it does not affect Type 3. Finally, companies focusing on further training either only rely on age-specific HR instruments with (Type 4) or without (Type 3) recruiting older employees. This, too, confirms the results of the separate estimations as described. We can therefore conclude that internal and external HRMstrategy do not contradict each other.

The existence of a works council as well as a company's tariff-commitment promote the choice for an internal strategy (Type 3), but also have a positive effect on the combination of the internal and external strategy (Type 4). In contrast, companies bound by collective agreement and companies with a works council are not likely to rely exclusively on the external strategy, that is, recruitment of older people (Type 2). This also confirms the result reported above.

The share of qualified employees is the most interesting variable in this model because the connection with the strategy type is different for every type: The share of qualified employees has a significantly negative relationship with Type 2, that is, it is smaller than in reference to Type 1, which neither conducts age-specific measures nor recruits older people. It has a significantly positive relationship with Type 3 (internal strategy without recruitment of older people), and it significantly differs with reference to Type 4 (combined strategy). This represents more evidence that high-quality operational human

Table 5 Determinants of the four company types (multinomial logit estimations), 2011. Source: IAB Establishment Panel 2011; own calculations

$\begin{array}{lll}\text { Recruitment but no HR measures } & \text { HR measures but no recruitment } & \text { Both } \\ \text { Type } 2 & \text { Type 3 } & \text { Type 4 }\end{array}$

\begin{tabular}{|c|c|c|c|}
\hline \multicolumn{4}{|l|}{ Resources } \\
\hline Company size & $0.935^{* * *}(0.037)$ & $0.679^{* * *}(0.046)$ & $1.511^{* * *}(0.043)$ \\
\hline HRM-Index & $-0.038(0.036)$ & $0.323^{* * *}(0.042)$ & $0.235^{* * *}(0.039)$ \\
\hline Further training & $-0.390^{* * *}(0.073)$ & $0.509^{* * *}(0.123)$ & $0.512^{* * *}(0.113)$ \\
\hline \multicolumn{4}{|l|}{ Experiences with older employees } \\
\hline Share of older employees & $2.187^{* * *}(0.174)$ & $2.427^{* * *}(0.237)$ & $3.667^{* * *}(0.221)$ \\
\hline \multicolumn{4}{|l|}{ Context of work relations } \\
\hline Works council & $-0.174^{* * *}(0.086)$ & $0.697^{* * *}(0.103)$ & $0.603^{* * *}(0.093)$ \\
\hline Collective agreement & -0.01014 & $0.383^{* * *}(0.092)$ & $0.199 * *(0.016)$ \\
\hline Need for skilled workers & $0.224^{* * *}(0.072)$ & $0.319^{* * *}(0.092)$ & $0.458^{* * *}(0.083)$ \\
\hline Labour turnover & $1.377^{* * *}(0.165)$ & $-0.493(0.316)$ & $0.965^{* * *}(0.203)$ \\
\hline \multicolumn{4}{|c|}{ Job requirements/work environment: } \\
\hline Share of skilled workers & $-0.336^{* * *}(0.123)$ & $0.559^{* * *}(0.190)$ & $0.114(0.159)$ \\
\hline Modern technical equipment & $0.063(0.066)$ & $0.149(0.092)$ & $0.011(0.081)$ \\
\hline Investments & $-0.163^{* *}(0.065)$ & $0.085(0.089)$ & $0.168^{*}(0.082)$ \\
\hline Sector affiliation (10 dummies) & Incl. & Incl. & Incl. \\
\hline N & 9240 & & \\
\hline Pseudo $R^{2}$ & 0.2551 & & \\
\hline
\end{tabular}

Reference category: neither age-specific personnel measures nor recruitments (type 1). ${ }^{*} p<0.10,{ }^{* *} p<0.05,{ }^{* * *} p<0.01$; standard errors in parentheses Basis: Establishments with older employees and recruitments 
capital with regard to older employees is rather produced or maintained internally than "bought" externally (from the labour market). The findings for technical equipment and investments are, however, not as obvious.

\section{Discussion and conclusion}

Against the background of a strongly increasing work participation of older employees and employees remaining on the labour market longer, this paper examined age-related Human resource strategies of firms. The question was how two different strategies of age-related HRM-measures relate to each other at company level. More specifically, we analysed whether companies using internal HRM-measures for older people, such as different measures of work design and further training, did this in addition to or instead of recruiting strategies targeting at older applicants.

We conducted two analyses based on the IAB Establishment Panel: On the one hand, we examined the determinants for the choice of either external or internal HRM towards older employees using logistic regressions. On the other hand, we classified companies according to whether they offer internal or external measures or both types (or neither) and the determinants that a company belongs to one of those four types using multinomial regressions. The results of both types of analysis converge in significant aspects.

The fact that there are four types of companies identified already shows that the question whether internal and external measures are used in a complementary or cumulative way cannot be answered definitively as an either-or question: There is both, that is, all four types of companies exist. Some companies can be assigned to the internal type $(31 \%)$ or the external type $(10 \%)$ at least from a statistical point of view (i.e. complementary); others, however, use the entire bandwidth of possibilities and insofar act in a cumulative way (12\%). The type using neither internal nor external measures represents the largest group (46\%, for the year 2011).

Our analysis of the determinants shows that there is no fundamental contradiction between the two HR management strategies. Some of the factors favouring internal strategies also favour external strategies or a combination of both. This applies for company size, operational experiences with older employees and demand for skilled workers. Thus, with regard to these factors, the idea of accumulation and/or a stage model is appropriate. One might interpret this finding in such a way that companies initially invest in their existing staff, and with increasing experiences and a growing awareness of HR-problems takes the next step and focusses on older applicants.

However, not all factors point in the same direction in terms of strategy choices. Further training activities, institutionalised work relations (existence of a works council and binding collective agreements) as well as a high share of qualified employees among staff are positively associated with internal HR-measures and negatively associated with external HR-measures towards older employees. These characteristics favour a company tending rather towards an external or internal strategy. An important conclusion from this finding is that it can be counter-productive only to wait for improving the recruitment opportunities for older people until a sufficient number of companies have gained trust in the performance capability of older people or the lack of skilled workers has increased. A policy which would only wait would be misleading because there are factors favouring the investment in existing staff and at the same time, isolating them from the outside. Rather, labour market policy should go on in supporting enterprises and older employees, e.g. by supporting further training and ageappropriate work organization. It also seems to be important to improve the information of companies concerning best practice projects or funding opportunities and hence help to reduce implementation problems (e.g., Richter and Mühlenbrock 2018). Initiatives such as INQA (Initiative New Quality of Work) as well as collective bargaining parties offer agreements and instruments for this purpose and could therefore play a special role in this context (e.g., Brandl et al. 2018).

Labour market policy should also support older jobseekers in getting a job, and should support enterprises to make it easier for them to test older job candidates, e.g. by supporting learning periods, test employment, and wage subsidies (e.g., Walwei 2018 or Dietz and Walwei 2011). An example is the so-called Entgeltsicherung-a wage support program for older workers which had been place in Germany between 2033 and 2011. However, take-up rates of this program had been rather low, which might had been due to a lack of information on the program (Brussig et al. 2006, van den Berg et al. 2017). This confirms, once again, the importance of advisory and information supply activities.

The findings presented here contribute to the debate about an age-appropriate working world (cf. e.g. Frerichs 2014, Ilmarinen 2005, Federal Ministry for Labour and Social Affairs (Bundesministerium für Arbeit und Soziales 2012, 2013a, b, 2014). They present detailed insight on the factors or reasons affecting certain human resource related actions of companies, such as recruiting and age-specific HRM. At the same time, we must point to an important limitation of the present analysis: Due to data availability, it is a snapshot in time. Further research should focus on the development of age-specific HRM-policies. In particular, of special interest are drivers for changing age-specific HRM-policies. To know 
why age-specific HRM-policies change would allow informed guesses about the consequences of challenges for employment prospects of older workers, such as the inflow of migrants in the German employment system, or the consequences of digitalization for older workers.

\section{Authors' contributions}

The manuscript is a joint work of MB and UL. Both authors read and approved the final manuscript.

\section{Competing interests}

The authors declare that they have no competing interests.

\section{Author details}

${ }^{1}$ Institut Arbeit und Qualifikation (IAQ), Universität Duisburg-Essen, 47048 Duisburg, Germany. ${ }^{2}$ Institut für Arbeitsmarkt- und Berufsforschung (IAB), Regensburger Str. 104, 90478 Nuremberg, Germany.

Received: 23 February 2017 Accepted: 27 November 2019 Published online: 16 December 2019

\section{References}

Akerlof, G.C.: Labor contracts as partial gift exchange. Q. J. Econ. 97(4), 543-569 (1982)

Althaauser, R.P., Kalleberg, A.: Firms, occupations, and the structure of labor markets: A conceptual analysis. In: Berg, I.E. (ed.) Sociological perspectives on labor markets, pp. 119-149. Academic Press, New York (1981)

Becker, G.S.: Human Capital. A Theoretical and Empirical Analysis with Special Reference to Education. 3. Aufl, 3rd edn. The University of Chicago Press, London (1993)

Bellmann, L.: Kontinuität und Veränderung des IAB-Betriebspanels. J Labour Market Res 47(1-2), 5-26 (2014)

Bellmann, L., Leber, U.: Weiterbildung für Ältere in KMU. Sozialer Fortschritt $\mathbf{5 7}(2), 43-48$ (2008)

Brandl, S., Guggemos, P., Matuschek, l.: Vom Einzelfall zum systematischen Alter(n)smanagement in KMU. WSI-Mitteilungen 1(12018), 51-58 (2018)

Brussig, M.: Betriebliche Personalwirtschaft in einer alternden Erwerbsbevölkerung. Zeitschrift für Management 2(2), 198-223 (2007)

Brussig, M., Bellmann, L.: Betriebliche Einflussfaktoren auf Rekrutierungen Älterer und deren Bewerbungen. Zeitschrift für Personalforschung 22(1), 35-57 (2008)

Brussig, M., Knuth, M.: Am Vorabend der Rente mit 67: Erkenntnisstand und Erkenntnislücken zur Entwicklung der Erwerbschancen Älterer. WSIMitteilungen 64(3), 99-106 (2011)

Brussig, M.: Neueinstellungen im Alter: Tragen sie zu verlängerten Erwerbsbiografien bei? (Altersübergangs-Report, 2011-03). Online verfügbar unter http://www.iaq.uni-due.de/auem-report/2011/2011-03/auem2011-03. pdf. (2011)

Brussig, M., Bernhard, S., Jaenichen, U., Zwick, T.: Zielstellung, Förderstrukturen und Effekte der Entgeltsicherung-Erfahrungen mit einem Kombilohn für "ältere Arbeitnehmerinnen und Arbeitnehmer. Zeitschrift für Arbeitsmarktforschung 39, 491-504 (2006)

Bundesministerium für Arbeit und Soziales (2012): Fortschrittsreport „Altersgerechte Arbeitswelt". Ausgabe 1: Entwicklung des Arbeitsmarkts für Ältere. Berlin

Bundesministerium für Arbeit und Soziales (2013a): Fortschrittsreport „Altersgerechte Arbeitswelt". Ausgabe 3: Länger gesund arbeiten. Berlin

Bundesministerium für Arbeit und Soziales (2013b): Fortschrittsreport „Altersgerechte Arbeitswelt". Ausgabe 2: Altersgerechte Arbeitsgestaltung. Berlin

Bundesministerium für Arbeit und Soziales (2014): Fortschrittsreport „Altersgerechte Arbeitswelt". Ausgabe 4: Lebenslanges Lernen und betriebliche Weiterbildung. Berlin

Crozier, M., Friedberg, E.: Macht und Organisationen. Die Zwänge kollektiven Handelns, Königstein/Ts (1979)
Dalen, V., Hendrik, P., Henkens, K., Schippers, J.: Dealing with older workers in Europe: a comparative survey of employers' attitudes and actions. J. Eur. Soc. Policy 19(1), 47-60 (2009)

Daniel, K., Heywood, J.S.: The determinants of hiring older workers: UK evidence. Labour Economics 14, 35-51 (2007)

Dietz, M., Walwei, U.: Germany - no country for old workers? Zeitschrift für ArbeitsmarktForschung 44(4), 363-376 (2011)

Doeringer, P.B., Piore, M.J.: Internal labor markets and manpower analysis. Heath Lexington Books, Lexington, Mass. (1971)

Frerichs, F.: Demografischer Wandel in der Erwerbsarbeit - Risiken und Potentiale alternder Belegschaften. In: Journal for Labour Market Research, Online First (2014)

Fröhler, N., Fehmel, T., Klammer, U.: Flexibel in die Rente. Gesetzliche, tarifliche und betriebliche Perspektiven. Berlin: edition sigma (2013)

Göbel, C., Zwick, T.: Are personnel measures effective in increasing productivity of old workers? Labour Econ. 22, 80-93 (2013)

Heywood, J.S., Jirjahn, U., Tsertsvardze, G.: Hiring older workers and employing older workers: German evidence. J. Popul. Econ. 23, 595-615 (2010)

Hutchens, R.: Delayed payment contracts and a firm's propensity to hire older workers. J. Labor Econ. 4, 439-457 (1986)

Ilmarinen, J.: Der Hausbau in der Praxis. Neue Ergebnisse aus internationalen Betriebsprojekten. presentation at the WAI conference, 7.3.2017, Berlin (2017)

Ilmarinen, J.: Towards a longer worklife: ageing and the quality of worklife in the European Union. Finnish Institute of Occupational Health, Ministry of Social Affairs and Health (2005)

Kistler, E., Trischler, F.: Reformen auf dem Arbeitsmarkt und in der Alterssicherung - Folgen für die Einkunftslage im Alter. Düsseldorf (edition der Hans-Böckler-Stiftung, 196) (2014)

Köhler, C., Loudovici, K.: Betriebliche Beschäftigungssysteme und Arbeitsmarktsegmentation. In: Christoph Köhler, Olaf Struck, Michael Grotheer, Alexandra Krause, Ina Krause und Tim Schröder (ed.): Offene und geschlossene Beschäftigungssysteme. Determinanten, Risiken und Nebenwirkungen. 1. Aufl. Wiesbaden: VS Verlag für Sozialwissenschaften, 31-63 (2008)

Köhler, C., Struck, O., Grotheer, M., Krause, A., Krause, I., Schröder, T.: Offene und geschlossene Beschäftigungssysteme. Determinanten, Risiken und Nebenwirkungen. 1. Aufl. Wiesbaden: VS Verlag für Sozialwissenschaften. Online verfügbar unter http://www.worldcat.org/oclc/311302042 (2008)

Leber, U., Stegmaier, J., Tisch, A.: Altersspezifische Personalpolitik: Wie Betriebe auf die Alterung ihrer Belegschaften reagieren. Institut für Arbeitsmarktund Berufsforschung. Nürnberg (IAB-Kurzbericht, 13/2013) (2013)

Lutz, B.: Arbeitsmarktstruktur und betriebliche Arbeitskräftestrategie. Eine theoretisch-historische Skizze zur Entstehung betriebszentrierter Arbeitsmarktsegmentation. Frankfurt/M., New York: Campus (1987)

Machado, C. S.: Hiring older workers: evidence from a longitudinal matched employer-employee dataset (2012)

Marsden, D.: A theory of employment systems. Micro-foundations of societal diversity. Oxford University Press, Oxford (1999)

Mincer, J.: Human capital theory: A review. In: Clark, S.P. (ed.) Labor economics and industrial relations. Markets and institutions, pp. 109-141. Harvard University Press (Wertheim publications in industrial relations), Cambridge (1994)

Osterman, P.S.: Internal labor market: Theory and change. In: Clark, S.P. (ed.) Labor economics and industrial relations. Markets and institutions, pp. 303-339. Harvard University Press (Wertheim publications in industrial relations), Cambridge (1994)

Richter, G., Mühlenbrock, I.: Herausforderungen und Handlungsbedarfe einer alternss- und altersgerechten Arbeitsgestaltung. WSI-Mitteilungen 1(2018), 28-35 (2018)

Rosenow, J.: Karriere- und Lebenslaufpolitik in deutschen Unternehmen gesellschaftliche Rahmenbedingungen und politische Regulierungen. In: George, R., Struck, O. (eds.) Generationsaustausch im Unternehmen, pp. 141-156. Rainer Hampp Verlag, München und Mering (2000)

Rump, J., Eilers, S.: Employability Management - lebenslange Beschäftigungsfähigkeit als Antwort auf den demografischen Wandel, in: Forschungsinstitut betriebliche Bildung f-bb (ed..): Demografischer Wandel und Weiterbildung, Strategien einer alterssensiblen Personalpolitik, Bielefeld, 39-58 (2007) 
Sengenberger, W.: Struktur und Funktionsweise von Arbeitsmärkten. CampusVerlag, Die Bundesrepublik Deutschland im internationalen Vergleich. Frankfurt/New York (1987)

Stecker, C., Zierler, C.: Erhalt der Arbeitsfähigkeit von Generationen. Die Bedeutung von Führung. In: WSI-Mitteilungen 1/2018, 36-43 (2018)

Struck, O.: Betriebliche Lebenslaufpolitik. In: Sackmann, R., Weymann, A., Wingens, M. (eds.) Die Generation der Wende, pp. 135-167. Leske + Budrich, Opladen (2000)

Trischler, F., Kistler, E.: Gute Erwerbsbiographien. Arbeitsbedingungen und Erwerbsverlauf. Stadtbergen (Arbeitspapier, 2) (2010)

van den Berg, G. J., Homrighausen, P., Stephan, G.: Targeted wage support for older unemployed workers. An evaluation combining survey and register data from a randomized controlled field experiment. LASER discussion papers, 100, Erlangen (2017)
Walwei, U.: Trends in der Beschäftigung Älterer. Rahmenbedingungen für betriebliche Personalpolitik. In: WSI-Mitteilungen 1/2018, 3-11 (2018)

Zwick, T.: Die Beschäftigungskonsequenzen von Senioritätsentlohnung in Deutschland. In: Uschi Backes-Gellner und Stephan Veen (ed.): Altern, Arbeit und Betrieb. Stuttgart: Wissenschaftliche Verlagsanstalt (Nova Acta Leopoldina NF 101, Nr. 365 (Altern in Deutschland, Bd. 3)), 79-87 (2009a)

Zwick, T: Senioritätsentlohnung in Deutschland im internationalen Vergleich. In: Uschi Backes-Gellner und Stephan Veen (ed.): Altern, Arbeit und Betrieb. Stuttgart: Wissenschaftliche Verlagsanstalt (Nova Acta Leopoldina NF 101, Nr. 365 (Altern in Deutschland, Bd. 3)), 79-87 (2009b)

\section{Publisher's Note}

Springer Nature remains neutral with regard to jurisdictional claims in published maps and institutional affiliations.

\section{Submit your manuscript to a SpringerOpen ${ }^{\circ}$ journal and benefit from:}

- Convenient online submission

- Rigorous peer review

- Open access: articles freely available online

- High visibility within the field

- Retaining the copyright to your article

Submit your next manuscript at $\boldsymbol{\nabla}$ springeropen.com 